
МОТИВАЦІЯ ТРУДОВОЇ ДІЯЛЬНОСТІ В УМОВАХ
СТАЛОГО РОЗВИТКУ АГРАРНОЇ СФЕРИ

\title{
MOTIVATION OF LABOR ACTIVITY IN THE CONDITIONS OF SUSTAINABILITY OF THE AGRARIAN SPHERE
}

Удк 331.1:658.3

DOI: https://doi.org/10.32843/bses.48-13

Васильєва О.O.

к.ф.-м.н., доцент,

доцент кафредри економіки

та митної справи

Національний університет

«Запорізька політехніка»

Vasylieva Olena

National University

"Zaporizhzhya Polytechnic" у статmі розглянуто вплив матеріальних та нематеріальних фракторів мотивації на продуктивну діяльність трудового потенціалу аграрної сорери в умовах сталого розвитку. Неоднозначний вплив зовнішніх специфрічних умов на сільськогосподарське виробництво може бути скомпенсований внутрішніми чинниками, до яких належить мотивація трудової діяльності. Експертна оцінка матеріальних та нематеріальних чинників, задоволеності працею та умов праці у сільському господарстві виявила позитивні кореляції між матеріальними та нематеріальними аспектами трудовоі діяльності. Використана експертна оцінка мотиваційних потреб трудової діяльності рунтується на психологічних потребах у компетентності, спорідненості, самостійності, залученні до цікавої діяльності. Проєктування дієвої системи мотивації прац в аграрній сорері має враховувати сучасну ситуацію та стан трудового потенціалу, взаємообумовленість грошових та негрошових стимулів, спиратись на світовий досвід вибору пріоритетних напрямів мотиваційної політики.

Ключові слова: мотивація, сталий розвиток, аграрна ссрера, задоволеність працею, соціально-психологічний клімат

В статье рассмотрено влияние материальных и нематериальных фракторов мотивации на продуктивную деятельность трудового потенциала аграрной сореры в условиях устойчивого развития. Неоднозначное влияние внешних специсических условий на сельскохозяйственное производство может быть скомпенсировано внутренними факторами, к которым относится мотивация трудовой деятельности. Экспертная оценка материальных и нематериальных факторов, удовлетворенности трудом и условий труда в сельском хозяйстве обнаружила положительные корреляции между материальными и нематериальными аспектами трудовой деятельности. Использованная экспертная оценка мотивационных потребностей трудовой деятельности основывается на психологических потребностях в компетентности, родстве, самостоятельности, приобщении к интересной деятельности. Проектирование эффрективной системы мотивации труда в аграрной сорере должно учитывать современную ситуацию и состояние трудового потенциала, взаимообусловленность денежных и неденежных стимулов, опираться на мировой опыт выбора при оритетных направлений мотивационной политики.

Ключевые слова: мотивация, устойчивое развитие, аграрная сорера, удовлетворенность трудом, социально-психологчческий климат.

The problems of motivation as a factor in increasing the rate of socio-economic development of the national economy, on the one hand, and as a biological and psychological impact on human productive activity, on the other hand, remain relevant to a sustainable development economy. Social indicators of sustainable development include the level of material well-being, the availability of benefits, social protection and more. The intangible factors of motivation in the agrarian sphere and their relationship with the material in the context of sustainable development remain unexplored. The purpose of the study is to analyze the influence of material and intangible factors of motivation on the productive activity of labor potential of the agricultural sector in the conditions of sustainable development. The article deals with the influence of material and intangible factors of motivation on the productive activity of labor potential of the agricultural sector in the conditions of sustainable development. Statistical Package for Statistical Sciences was used for statistical analysis of the data, as well as correlation-regression analysis. Expert evaluation of material and intangible factors, job satisfaction and working conditions in agriculture revealed positive correlations between material and intangible aspects of work. More than half of the agricultural experts highly assess the involvement in the category of agrarians, favorable social and psychological climate in the team, relations with management and the existence of a collective agreement. Most worrying is financial factors, whose average score is rather low. The expert evaluation of the motivational needs of work is based on psychological needs in competence, affinity, independence, involvement in interesting activities. Comparison of built-in regression models demonstrates the positive impact of constant employment and high basic wages on the assessment of social and psychological climate in the team and satisfaction with employment, and a positive perception of working conditions includes satisfaction with employment. Designing an effective system of labor motivation in the agricultural sector should take into account the current situation and the state of labor potential, the interdependence of monetary and non-monetary incentives, based on the world experience of choosing priority areas of motivational policy.

Key words: motivation, sustainability, agrarian sphere, labor satisfaction, social psychological climate.

Постановка проблеми. Людина як носій трудового потенціалу постійно перебуває в центрі уваги цивілізованого суспільства. Ставлення людини до праці визначають ціннісні орієнтири й рівень соціальної та інтелектуальної свідомості, потреби та можливості їх задоволення, які на практиці трансорормуються в конкретні мотиви трудової поведінки, що є складовими індикаторів сталого розвитку, рушійними силами людської діяльності. Проблеми мотивації як фрактору підвищення темпів соціально-економічного розвитку національного господарства, з одного боку, та як біологічного й психологічного впливу на продуктивну діяльність людини, 3 іншого боку, залишаються актуальними для економіки сталого розвитку, до соціальних параметрів якої належать рівень матеріального благополуччя, доступність благ, соціальну захищеність тощо.

Аналіз останніх досліджень і публікацій. Питанням трудової мотивації присвячені дослідження багатьох зарубіжних на вітчизняних учених, зокрема економістів, психологів, соціологів та управлінців. Теоретико-методологічні засади мотивації праці в аграрній сорері висвітлені в 
роботах А. Бабенка, О. Бугуцького, В. Дієсперова, М. Жибака, А. Колота, В. Лагодієнка, І. Лукінова, Т. Олійник, М. Семикіної, Л. Червінської, О. Черепа, О. Шпичака, В. Юрчишина та інших учених. Проте, на наш погляд, нематеріальні чинники мотивації в аграрній сорері та їх взаємоз'язок з матеріальними в умовах сталого розвитку залишаються малодослідженими.

Постановка завдання. Метою дослідження $€$ аналіз впливу матеріальних та нематеріальних фракторів мотивації на продуктивну діяльність трудового потенціалу аграрної сфрери в умовах сталого розвитку.

Виклад основного матеріалу дослідження. 3 позицій соціально-економічного підходу аграрна сорера розглядається як система, ядром якої $€$ базова галузь, а саме сільське господарство, що функціонує в сільському середовищі, зумовлює специфріку виробництва, життєвий рівень сільського населення та умови його діяльності [1, с. 31]. До індикаторів сталого розвитку аграрної сорери відносять соціальні, економічні та екологічні показники. Соціальні чинники включають зростання доходів, рівень життя сільського населення, якість людських ресурсів, захищеність життєдіяльності, що визначаються економічною та соціальною поведінкою людини. Сільське господарство як системоутворюючий елемент аграрної сорери має особливості, що полягають «у використанні засобів виробництва природного походження: рослинних і тваринних організмів, водних ресурсів, а також кліматичних ресурсів - світла, тепла, опадів тощо» [2, с. 128]. Застосування специфічних засобів аграрного виробництва, що комплементарно пов'язані 3 довкіллям та його природніми законами, обмежує можливості економічного зростання. Неоднозначний вплив зовнішніх умов на сільськогосподарське виробництво може бути скомпенсований внутрішніми чинниками, до яких належать застосування прогресивних технологій, забезпеченість кваліфікованими кадрами, ефективність використання персоналу та мотивація його трудової діяльності [3, с. 60].

Інтенсиорікація економічного життя країни загалом приводить до ускладнення організаційних фрорм ведення бізнесу, фрормування нових підходів до управління. Праця в аграрній сорері має свої особливості, зумовлені специфікою сільськогосподарських процесів. Так, висока частка операцій безпосередньо пов'язана з непідвладними людині чинниками (природні умови, катаклізми тощо), що зумовлюють значні затрати організаційних, людських та часових ресурсів. Одним 3 ключових факторів вдалого ведення аграрного бізнесу стає рівень задоволеності працею.

Поняття задоволеності працею $€$ комплексним та включає оцінку різних його складових. Експертне оцінювання проводилось серед пра- цівників сільськогосподарських підприємств та Департаменту агропромислового розвитку (ДАПР) Запорізької області. Запропонований для аналізу перелік аспектів умовно розділений на соціальнопсихологічні (з 1.1 по 1.18) та фрінансові (3 2.1 по 2.18) чинники (табл. 1). Все, що мотивує або заохочує працівників бути ефективнішими, розглядається як чинник підвищення ефективної роботи, включає грошові та негрошові стимули. Для статистичного аналізу даних використано програмне забезпечення SPSS (Statistical Package for the Social Sciences). Як видно з результатів дослідження, більше половини опитаних працівників сільськогосподарських підприємств високо оцінюють (від 7 балів та вище) 18336 складових (табл. 1). Топ-4 становлять причетність до категорії аграріїв; сприятливий соціально-психологічний клімат у колективі; відносини 3 керівництвом та наявність колективного трудового договору. Найбільше занепокоєння викликають фрінансові чинники, середня оцінка яких коливається від 1,8 до 7,0 балів 310 можливих. Топ-6 становлять доплата за високу оцінку після атестації; можливість отримання пільгових кредитів від підприємства; одноразові виплати за підвищення кваліфрікації та професійного рівня; компенсація витрат на харчування; надбавка за стаж; доплата пенсіонерам.

До категорії «Нижче середнього» належать оцінки від 0 до 3 балів; «Середній» - від 4 до 6 балів; «Вище середнього» - від 7 до 10 балів.

Мотиваційний вплив на трудову поведінку може залежати від різник культур, цінностей, обставин, гендерної приналежності [4, с. 12]. Оцінка аспектів праці визначається індивідуальними соціальнодемографічними показниками, такими як стать, вік, освіта, а також організаційними факторами, такими як розмір сільськогосподарського підприємства (площа сільськогосподарських угідь та кількість працівників), посада та стаж роботи працівника.

Перманентне вивчення питань як матеріальної, так і нематеріальної мотивації показує, що працівники, крім фрінансової складової, віддають перевагу таким питанням, як визнання (вдячність за виконану роботу), цікава робота, гордість за організацію, стосунки 3 колегами, відносини 3 керівництвом, здатність представляти ідеї управління [5]. Гроші будуть основною фрормою мотивації доти, поки працівники не відчують, що ці категорії потреб задоволені [4, с. 61]. В дослідженнях мотиваційних чинників працівників ферм у Швеції, проведених К. Колструп, до переліку дієвих фрорм мотивації віднесені веселощі на роботі, приємне керівництво, почуття гордості за свою роботу, статус професії аграрія, безпека праці та гарний командний дух [6, с. 5311-5314].

За результатами порівняльного аналізу середніх оцінок різних сторін праці представники сільськогосподарських підприємств $є$ більш позитивно 
Розподіл відповідей на запитання «Оцініть, будь ласка, в балах, наскільки Ви задоволені певними аспектами Вашої праці», \%

\begin{tabular}{|c|c|c|c|c|}
\hline № & Питання & $\begin{array}{c}\text { Нижче } \\
\text { середнього }\end{array}$ & Середній & $\begin{array}{c}\text { Вище } \\
\text { середнього }\end{array}$ \\
\hline 1.1 & Постійна трудова зайнятість & 1 & 33 & 66 \\
\hline 1.2 & Наскільки цінують Ваш досвід та кваліфрікацію? & 2 & 27 & 71 \\
\hline 1.3 & Можливість кар'єрного зростання & 33 & 37 & 30 \\
\hline 1.4 & Конкурентоспроможність на ринку праці & 6 & 39 & 55 \\
\hline 1.5 & Можливість підвищення кваліфрікації & 18 & 46 & 36 \\
\hline 1.6 & Задоволеність від заняття улюбленою справою & 3 & 35 & 62 \\
\hline 1.7 & Сприятливий соціально-психологічний клімат у колективі & 1 & 6 & 93 \\
\hline 1.8 & Сприятливі умови праці & 3 & 34 & 63 \\
\hline 1.9 & Участь в управлінні колективом & 41 & 25 & 34 \\
\hline 1.10 & Причетність до категорії аграріїв & 5 & 6 & 89 \\
\hline 1.11 & $\begin{array}{l}\text { Можливість зміни монотонного трудового процесу на більш } \\
\text { цікавий, творчий, змістовний }\end{array}$ & 54 & 27 & 19 \\
\hline 1.12 & Гнучкий графрік роботи або додатковий вихідний день & 24 & 36 & 40 \\
\hline 1.13 & Публічна похвала за результатами роботи & 4 & 18 & 78 \\
\hline 1.14 & Урочисті вечори, корпоративні свята & 18 & 19 & 63 \\
\hline 1.15 & Можливість отримання житла & 92 & 6 & 2 \\
\hline 1.16 & Можливість влаштування дитини у дитячий садок & 53 & 6 & 41 \\
\hline 1.17 & Наявність колективного трудового договору & 9 & 3 & 88 \\
\hline 1.18 & Відносини з керівництвом & 1 & 17 & 82 \\
\hline 2.1 & Висока базова заробітна плата & 3 & 31 & 66 \\
\hline 2.2 & Премії за результатами роботи & 7 & 32 & 61 \\
\hline 2.3 & «13-а зарплата» & 21 & 32 & 47 \\
\hline 2.4 & Виплати за перевиконання плану & 29 & 48 & 23 \\
\hline 2.5 & Надбавка за стаж & 51 & 41 & 8 \\
\hline 2.6 & Доплати за професіоналізм, кваліфікацію & 35 & 38 & 27 \\
\hline 2.7 & Одноразові виплати за підвищення кваліфікації & 71 & 22 & 7 \\
\hline 2.8 & Доплата за високу оцінку після атестації & 75 & 21 & 4 \\
\hline 2.9 & Участь у прибутку (виплати за паями або акціями) & 46 & 19 & 35 \\
\hline 2.10 & Можливість отримання пільгових кредитів від підприємства & 68 & 29 & 3 \\
\hline 2.11 & Компенсація витрат на харчування & 69 & 16 & 15 \\
\hline 2.12 & Компенсація витрат на навчання та підвищення кваліфікації & 42 & 21 & 37 \\
\hline 2.13 & Компенсація витрат на проїзд & 31 & 14 & 58 \\
\hline 2.14 & Компенсація витрат на оздоровлення & 17 & 24 & 59 \\
\hline 2.15 & Забезпечення спецодягом & 14 & 33 & 53 \\
\hline 2.16 & Подарунки до ювілеїв & 21 & 17 & 62 \\
\hline 2.17 & Виплати у зв'язку з виходом на пенсію & 14 & 22 & 64 \\
\hline 2.18 & Доплати пенсіонерам & 58 & 34 & 8 \\
\hline
\end{tabular}

налаштованими у своїх судженнях, ніж працівники Департаменту агропромислового розвитку (АПР) Запорізької області. При цьому фрінансові чинники низько оцінюються обома категоріями опитаних. Відмінність полягає в тому, що працівники аграрного сектору більшою мірою задоволені базовою заробітною платою, участю в прибутку, виплатою у зв'язку з виходом на пенсію.

Певною мірою на рівень задоволеності тими чи іншими аспектами праці впливають такі чинники, як розмір посівних угідь та кількість працівників підприємства. Це пов'язано з тим, що чим більше господарство, тим більше в нього фрінансових та організаційних можливостей для задоволення потреб своїх 
На підприємствах з чисельністю понад 100 працівників більш високо оцінюють такі аспекти праці, як компенсація витрат на навчання та підвищення кваліфрікації; компенсація витрат на проїзд; надбавки за стаж. Задоволеність соціально-психологічними складовими майже не змінюється залежно від кількості працівників, тоді як зміна оцінки фрінансових чинників $€$ більш помітною: чим більше робітників на підприємстві, тим вище рівень їх значущості.

Цікавим $€$ те, що в дрібних сільськогосподарських підприємствах більш високо оцінюють такі фрінансові елементи, як, наприклад, премії за результати роботи, подарунки до ювілеїв, виплати у зв'язку з виходом на пенсію.

У світовій практиці мотивації широко використовуються теорія дизайну робочих місць Гекмана-Олдхема та сертифікація компетентностей [7, с. 197]. Забезпечення гідних умов праці та розвиток персоналу покладаються на керівників підприємств, організацій, компаній. Саме вони мають відслідковувати потреби своїх працівників та швидко реагувати на зміни настрою в колективі для забезпечення комфортних умов роботи, що приводить до підвищення продуктивності праці, прибутку тощо.

Посадовий рівень працівника позитивно впливає на його оцінку задоволеності працею, оскільки з підвищенням посади, як правило, поліпшуються умови роботи, розширюються можливості та зростає ступінь автономності. За результатами дослідження керівники схильні більш високо оцінювати створені на підприємстві умови праці, найбільш стриманими у своїх судженнях є робітники.

Різниця в середніх оцінках сторін праці залежно від стажу роботи на підприємстві не перевищує 2,5 бали. При цьому чим більший стаж, тим більший рівень задоволеності. Зокрема, це стосується зниження оцінки можливості влаштувати дитину у дитячий садок, наявності колективного трудового договору та причетності до категорії аграріїв у робітників, які мають стаж роботи на підприємстві менше трьох років.

Оцінка різних складових праці є майже однаковою серед соціально-демографрічних категорій (стать, вік). Жінки мають більш оптимістичне сприйняття різних складових свого робочого процесу, ніж чоловіки. Це може бути обумовлено їх різними фрункціональними обов'язками на підприємстві, що визначає відмінності умов праці. Соціально-психологічними аспектами праці більшою мірою задоволені представники середньої вікової категорії (30-39 років) та старшого покоління (більше 60 років). Щодо фрінансових чинників, то, незважаючи на загальну тенденцію меншої міри задоволеності ними, найбільше занепокоєння викликає значення експертних оцінок у молоді віком до 29 років.
Оцінки аспектів праці залежно від рівня освіти $€$ майже однаковими. Однак працівники з вищою освітою порівняно з іншими категоріями схильні більш високо оцінювати участь в управлінні колективом, компенсацію витрат на навчання та підвищення кваліфрікації, можливість підвищення кваліфрікації та участь у прибутку (виплати за паями або акціями). Різниця значень цих складових робочого процесу коливається від 2,6 до 3,5 балів.

Реалізація процедури оракторного аналізу на отриманому масиві даних не дала бажаного результату. Багатофракторна модель оцінки чинників робочого процесу відзначається невисоким ступенем структурованості, а це вказує на те, що, з одного боку, практично всі перераховані складові мають значний вплив, а з іншого боку, цей вплив не залежить від фракту приналежності показника до тої чи іншої підгрупи, тобто до одного фрактору потрапляють як соціально-психологічні, так і фрінансові аспекти. Узагальнення щодо обґрунтування стану задоволеності працею потребує вивчення значущих взаємозв'язків між досліджуваними аспектами.

Згідно 3 результатами кореляційно-регресійний аналізу на формування позитивної оцінки соціально-психологічного клімату в колективі більшою мірою впливає рівень задоволеності такими складовими, як постійна трудова зайнятість, базова заробітна плата, компенсації витрат на оздоровлення та подарунки до ювілеїв, а найменший вплив має забезпечення спецодягом (рис. 1), тобто підвищення рівня задоволеності цими аспектами праці дасть змогу покращити оцінку соціально-психологічного клімату в колективі загалом. Найбільший вплив на фрормування позитивного судження щодо умов праці має задоволеність від заняття улюбленою справою, друге місце посідає можливість кар'єрного зростання. Меншою мірою впливають компенсація витрат на навчання та підвищення кваліфікації, урочисті вечори, корпоративні свята та доплата за просресіоналізм, кваліфікацію (рис. 2).

Зворотній вплив мають такі складові, як можливість отримання пільгових кредитів від підприємства, виплати у зв'язку з виходом на пенсію та гнучкий графрік роботи або додатковий вихідний.

Отримана в ході регресійного аналізу модель описує приблизно 70\% дисперсії задоволеності сприятливими умовами праці.

Майже однаковою мірою на задоволеність від заняття улюбленою справою впливають такі аспекти праці, як постійна трудова зайнятість, висока базова заробітна плата та сприятливі умови праці. Друге місце посідають виплати у зв'язку з виходом на пенсію.

Менший вплив мають такі характеристики, як гнучкий графрік роботи або додатковий вихідний день, можливість підвищення кваліфрікації та компенсація витрат на оздоровлення (рис. 3). 
Постійна трудова зайнятість

Висока базова заробітна плата

Компенсація витрат на оздоровлення

Подарунки до ювілеїв

0,166

0,125

Можливість влаштування дитини у дитячий садок

Забезпечення спецодягом

0,084

Компенсаця витрат на проїзд

Доплата за високу оцінку після атестації

Доплата пенсіонерам

$-0,158$

Рис. 1. Результати регресійного аналізу за аспектом «Сприятливий соціально-психологічний клімат у колективі» (у пунктах)

Задоволеність від заняття улюбленою справою

Можливість кар'єрного зростання

Компенсація витрат на навчання та підвищення кваліфікації

Урочисті вечори, корпоративні свята

Доплати за професіоналізм, кваліфікацію

Можливість отримання пільгових кредитів від підприємства

Виплати у зв'язку із виходом на пенсію

Гнучкий графік роботи або додатковийвихідний день

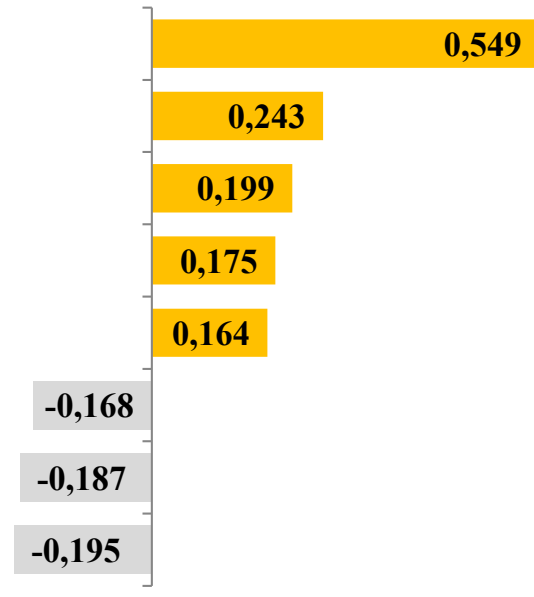

Рис. 2. Результати регресійного аналізу за аспектом «Сприятливі умови праці» (у пунктах)

Постійна трудова зайнятість

Висока базова заробітна плата

Сприятливі умови праці

Виплати у зв'язку із виходом на пенсію

Гнучкий графік роботи або додатковий вихідний день

Можливість підвищення кваліфікації

Компенсація витрат на оздоровлення

Наявність колективного трудового договору

Забезпечення спецодягом

Компенсація витрат на навчання та підвищення кваліфікації

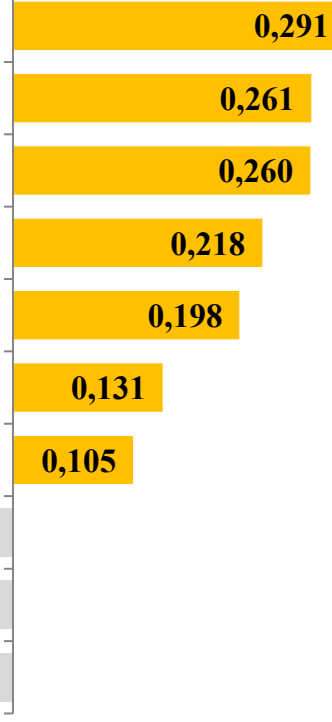

Рис. 3. Результати регресійного аналізу за аспектом «Задоволеність від заняття улюбленою справою» (у пунктах) 
Негативний вплив на задоволеність від заняття улюбленою справою здійснюють низькі оцінки наявності колективного трудового договору, забезпечення спецодягом, витрат на навчання та підвищення кваліфрікації.

Відповідно, рівняння регресії пояснює приблизно 86\% дисперсії задоволеності від заняття улюбленою справою та має такий вигляд:

$$
\begin{gathered}
\mathrm{Q}_{1.6}{ }^{\prime}=0,291_{\mathrm{Q} 1.1}{ }^{\prime}+0,261_{\mathrm{Q} 2.1}{ }^{\prime}+0,260_{\mathrm{Q} 1.8^{\prime}}+ \\
+0,218_{\mathrm{Q}_{2.17}}+0,198_{\mathrm{Q} 1.12}{ }^{\prime}+0,131_{\mathrm{Q} 1.5}{ }^{\prime}+0,105_{\mathrm{Q}_{2} \cdot 14}{ }^{\prime}- \\
-0,100_{\mathrm{Q} 1.17}{ }^{\prime}-0,114_{\mathrm{Q} 2.15}{ }^{\prime}-0,136_{\mathrm{Q} 2.12} .
\end{gathered}
$$

Згідно з результатами регресійного аналізу на формування позитивної оцінки соціально-психологічного клімату в колективі більшою мірою впливає рівень задоволеності забезпеченням спецодягом. Дещо менший вплив мають такі аспекти, як висока базова заробітна плата, виплати у зв'язку з виходом на пенсію, можливість кар'єрного зростання та участь в управлінні колективом. Найменшу вагу має такий чинник, як компенсація витрат на навчання та підвищення квалісрікації (рис. 4).

Зворотній вплив мають такі складові, як можливість отримання пільгових кредитів від підприємства, премії за результатами роботи та компенсація витрат на проїзд. Означена модель пояснює приблизно 80\% дисперсії задоволеності сприятливим соціально-психологічним кліматом у колективі.

Загалом рівняння регресії має такий вигляд:

$$
\begin{aligned}
& \mathrm{Q}_{1.7}{ }^{\prime}=0,353_{\mathrm{Q} 1.3}{ }^{\prime}+0,244_{\mathrm{Q} 2.1}{ }^{\prime}+0,222_{\mathrm{Q}_{2.17}{ }^{\prime}+} \\
& +0,214_{\mathrm{Q} 1.3}{ }^{\prime}+0,205_{\mathrm{Q} 1.9^{\prime}}+0,169_{\mathrm{Q}_{2} \cdot 12}{ }^{\prime}-0,248_{\mathrm{Q}_{2} \cdot 10^{\prime}}- \\
& --0,250_{\mathrm{Q} 2.2}{ }^{\prime}-0,288_{\mathrm{Q} 2,13}{ }^{\prime} .
\end{aligned}
$$

Згідно з результатами на фрормування позитивної оцінки сприятливих умов праці більшою мірою впливає рівень задоволеності можливістю кар'єрного зростання. Майже однаковою мірою впливають такі аспекти, як доплата за високу оцінку після атестації та компенсація витрат на навчання та підвищення кваліфрікації. Дещо менше значення мають такі складові, як забезпечення спецодягом та подарунки до ювілеїв (рис. 5).

Зворотній вплив мають такі чинники, як гнучкий графрік роботи або додатковий вихідний день, можливість влаштування дитину у дитячий садок, одноразові виплати за підвищення кваліфікації та профресійного рівня.

Найбільший вплив на фрормування позитивного судження щодо задоволеності від заняття улюбленою справою мають компенсація витрат на оздоровлення та постійна трудова зайнятість. Друге місце посідає можливість підвищення кваліфрікації. Негативний вплив на оцінку здійснює такий чинник, як компенсація витрат на харчування (рис. 6). Отримана модель пояснює приблизно 90\% дисперсії задоволеності від заняття улюбленою справою.

Порівняння цих регресійних моделей демонструє таке:

- такі аспекти праці, як постійна трудова зайнятість, висока базова заробітна плата, позитивно впливають на оцінку соціально-психологічного клімату в колективі та задоволеність від заняття улюбленою справою;

- позитивне сприйняття умов праці включає задоволеність від заняття улюбленою справою.

Згідно з отриманими результатами для підвищення рівня умов праці, соціально-психологічного клімату та задоволеності від заняття улюбленою справою перш за все необхідно звернути увагу на аспекти, які перетинаються в наведених моделях та взаємодоповнюють один одного. В табл. 2 наведені результати кореляційного аналізу, що відображають високо позитивні взаємозалежності між різними складовими робочого процесу.

Значну роль у формуванні позитивної оцінки задоволеності працею відіграють умови праці. Ïх удосконалення, узгодження 3 потребами та
Забезпечення спецодягом

Висока базова заробітна плата Виплати

у зв'язку із виходом на пенсію

Можливість кар'єрного зростання

Участь в управлінні колективом

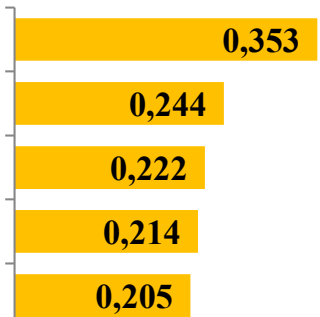

0,169

Компенсація витрат на навчання та підвищення кваліфікації Можливість отримання пільгових кредитів від підприємства

Премії за результатами роботи

Компенсація витрат на проїзд

\begin{tabular}{|c|c|} 
& \multicolumn{1}{|c|}{0,353} \\
& 0,244 \\
& 0,222 \\
\hline$-0,248$ & 0,214 \\
\hline$-0,250$ & 0,205 \\
\hline$-0,288$ & \\
\hline
\end{tabular}

Рис. 4. Результати регресійного аналізу за аспектом «Сприятливий соціально-психологічний клімат у колективі» (у пунктах) 
Можливість кар'єрного зростання

Доплата за високу оцінку після атестації

Компенсація витрат на навчання та підвищення кваліфікації

$$
\begin{gathered}
\text { Забезпечення спецодягом } \\
\text { Подарунки до ювілеїв }
\end{gathered}
$$

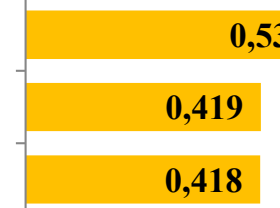

$\mathbf{0 , 2 8 7}$

0,247

Гнучкий графік роботи або додатковий вихідний день

Можливість влаштування дитини у дитячий садок

$-0,364$

Одноразові виплати за підвищення кваліфікації

$-\mathbf{0 , 4 1 1}$

Рис. 5. Результати регресійного аналізу за аспектом «Сприятливі умови праці» (у пунктах)

Компенсація витрат на оздоровлення

Постійна трудова зайнятість

Можливість підвищення кваліфікації

Компенсація витрат на харчування

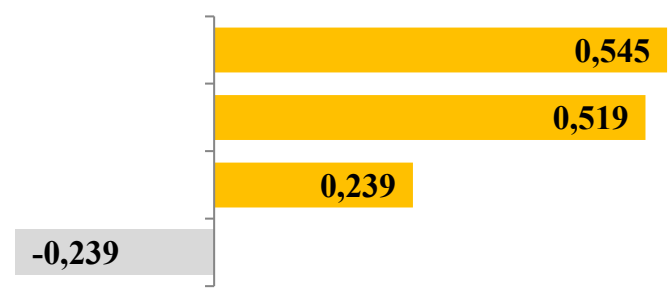

Рис. 6. Результати регресійного аналізу за аспектом «Задоволеність від заняття улюбленою справою» (у пунктах)

Результати кореляційного аналізу аспектів праці

\begin{tabular}{|c|c|}
\hline Аспект праці & Високо позитивна кореляція \\
\hline \multirow{8}{*}{$\begin{array}{l}\text { Задоволеність від заняття } \\
\text { улюбленою справою }\end{array}$} & Постійна трудова зайнятість \\
\hline & $\begin{array}{l}\text { Можливість зміни монотонного трудового процесу на більш цікавий, } \\
\text { творчий, змістовний }\end{array}$ \\
\hline & Відносини з керівництвом \\
\hline & Подарунки до ювілеїв \\
\hline & Гнучкий графік роботи або додатковий вихідний день \\
\hline & Сприятливі умови праці \\
\hline & Наскільки цінують Ваш досвід та кваліфікацію? \\
\hline & Участь в управлінні колективом \\
\hline \multirow{5}{*}{ Постійна трудова зайнятість } & Задоволеність від заняття улюбленою справою \\
\hline & $\begin{array}{l}\text { Можливість зміни монотонного трудового процесу на більш цікавий, } \\
\text { творчий, змістовний }\end{array}$ \\
\hline & Наскільки цінують Ваш досвід та кваліфікацію? \\
\hline & Сприятливий соціально-психологічний клімат у колективі \\
\hline & Гнучкий графрік роботи або додатковий вихідний день \\
\hline \multirow{3}{*}{ Сприятливі умови праці } & Можливість кар'єрного зростання \\
\hline & Задоволеність від заняття улюбленою справою \\
\hline & Сприятливий соціально-психологічний клімат у колективі \\
\hline \multirow{7}{*}{$\begin{array}{l}\text { Сприятливий соціально-психологічний } \\
\text { клімат у колективі }\end{array}$} & Відносини з керівництвом \\
\hline & Задоволеність від заняття улюбленою справою \\
\hline & Подарунки до ювілеїв \\
\hline & Публічна похвала за результати роботи (подяки, грамоти тощо) \\
\hline & Постійна трудова зайнятість \\
\hline & Наскільки цінують Ваш досвід та кваліфікацію? \\
\hline & Сприятливі умови праці \\
\hline
\end{tabular}

Таблиця 2 
здібностями визначально впливають на ставлення працівників до своєї трудової діяльності. Умови праці $є$ показником рівня соціального розвитку підприємства.

До характеристик умов праці можна віднести соціально-психологічний клімат у колективі, екологічне середовище, оснащення робочого місця, задоволеність роботою оргтехніки та інших технічних засобів. Згідно з результатами дослідження більше половини опитаних констатують наявність 10 з 11 запропонованих складових. Виконання невластивих посаді функцій притаманне більшій частині працівників аграрної сорери, про що говорять 56\% опитаних (табл. 3).

Порівняння фракту констатації наявності чи відсутності певної характеристики умов праці з рівнем її задоволеності демонструє, що сприятливий соціально-психологічний клімат у колективі оцінюється на 8,4 бали з 10 можливих серед працівників, які визнали, що він є таким на їх підприємстві. Частка тих, хто констатує наявність гнучкого графріку у їх господарстві, становить майже 70\%, при цьому середній бал цієї складової частини становить 6,4 з 10 можливих.

Аналізуючи характеристики умов праці, звертаємо увагу на такі моменти:

- частка задоволених оснащенням робочого місця більша серед працівників дрібних сільськогосподарських підприємств (до 1000 га), становлячи 89\%; робітники великих господарств (більше 3000 га) позитивно оцінюють (на рівні 74\% опитаних) наявність оптимального температурного режиму;

- необхідність виконання не властивих посаді функцій здебільшого притаманна дрібним та середнім підприємствам (з чисельністю працівників до 100 осіб), на що вказують більше 60\% опитаних цих категорій, однак їх перевагою $€$ використання гнучкого графріку роботи; працівники великих за чисельністю підприємств мають більш чітко закріплені фрункціональні обов'язки та графрік роботи; водночас вони краще забезпечені техніч- ними засобами та більшою мірою задоволені температурним режимом праці;

- частка керівників, які вважають, що на підприємстві використовується морально застаріла техніка, сягає позначки у 67\%; близько 60\% опитаних робітників вказують на наявність відволікаючих шумів під час роботи; цікавим є той фракт, що керівники на рівні з рядовими працівниками свого господарства виконують не властиві їх посаді фрункціональні обов'язки, на що вказують $60 \%$ опитаних обох категорій; частка задоволених роботою комп'ютера, принтера та інших технічних засобів більше серед фрахівців, професіоналів, службовців, становлячи 83\%, що майже на половину більше порівняно з іншими працівниками; така диспропорція обумовлена виконанням різних функціональних обов'язків на підприємстві і, відповідно, різними умовами праці;

- з роками на підприємстві працівники стають обізнаними з різних питань, тому вони частіше, ніж молоде покоління, виконують не властиві їх посаді фрунції; також це може бути обумовленим процесом передачі досвіду від старшого покоління до молодшого, яке ще не має необхідних практичних навичок;

- чоловіки мають більш гнучкий графрік роботи, однак вони більшою мірою змушені виконувати не властиві їх посаді фрункції; при цьому частка жінок, задоволених роботою оргтехніки та інших технічних засобів, становить 85\%, що майже на $40 \%$ більше, ніж серед чоловіків;

- працівники із загальною середньою освітою гостріше відчувають потребу у вдосконаленні умов праці, зокрема вони частіше вказують на відсутність оптимально оснащеного робочого місця, використання морально застарілої техніки та виконання не властивих їх посаді фрункцій.

Отже, використана методика експертної оцінки мотиваційних потреб трудової діяльності ґрунтується насамперед на психологічних потребах у компетентності, спорідненості, самостійності, основне задоволення потреб виникає частково

Таблиця 3

Розподіл відповідей на запитання щодо рівня згоди з нижченаведеними твердженнями, \%

\begin{tabular}{|c|l|c|c|}
\hline \multicolumn{1}{|c|}{ Питання } & Так & Hi \\
\hline 3.1 & Чи сприятливий соціально-психологічний клімат у колективі? & 99 & 1 \\
\hline 3.2 & Чи сприятливе екологічне середовище Вашої праці? & 90 & 10 \\
\hline 3.3 & Використовується гнучкий грасрік роботи? & 69 & 31 \\
\hline 3.4 & Чи оптимальне оснащення робочого місця? & 78 & 22 \\
\hline 3.5 & Чи достатнє освітлення? & 95 & 5 \\
\hline 3.6 & Чи достатньо виробничих площ? & 93 & 7 \\
\hline 3.7 & Чи оптимальний температурний режим? & 64 & 36 \\
\hline 3.8 & Відсутні відволікаючі шуми? & 67 & 43 \\
\hline 3.9 & Задовольняє робота комп'ютера, принтера та інших технічних засобів? & 37 \\
\hline 3.10 & Використовується морально застаріла техніка? & 38 & 62 \\
\hline 3.11 & Чи виконуєте не властиві Вашій посаді функції? & 56 & 44 \\
\hline
\end{tabular}


від залучення до цікавої діяльності [8, с. 57], але з огляду на негативні тенденції сучасного стану оплати праці у сільському господарстві, яка $€$ значно нижчою від середньої по економіці, та кризову ситуацію щодо формування та розвитку трудового потенціалу аграрної сорери (демографічний спад, міграція, старіння сільського населення, низький освітній рівень) матеріальна мотивація залишається вирішальним чинником ефективної трудової діяльності трудового потенціалу аграрної сорери.

Висновки з проведеного дослідження. Проєктування дієвої системи мотивації праці в аграрній сорері має враховувати сучасну ситуацію та стан трудового потенціалу, силу впливу матеріальних та нематеріальних фракторів мотивації на продуктивну діяльність, спиратись на світовий досвід вибору пріоритетних напрямів мотиваційної політики.

\section{БІБЛІОГРАФІЧНИЙ СПИСОК:}

1. Ємельянова Л. Сталий розвиток аграрної сорери України як об'єкт моделювання. Агросвіт. 2017. № 10. С. 30-34.

2. Бородіна О. Імперативи комплементарного розвитку в аграрній сфері. Економіка $і$ прогнозування. 2017. № 4. С. 125-136.

3. Лагодієнко В., Лагодієнко Н. Депопуляція сільських територій та мотивація найманих працівників у сорері сільськогосподарського виробництва України. Бізнес-навігатор. 2019. Вип. 5-1. С. 54-61.

4. Erwee Y. The motivation of farm workers: The case of seven Western Cape fruit farms, Cape Town: Graduate school of Business. 2016. URL: http:// gsblibrary.uct.ac.za/researchreports/2016/Erwee.pdf (дата звернення: 28.09.2019).

5. Sorauren I. Non-Monetary Incentives: Do People Work Only for Money? Business Ethics Quarterly. № 10 (4). P. 925-944. DOI: https://doi.org/10.2307/3857840.

6. Kolstrup C. What factors attract and motivate dairy farm employees in their daily work? Work. 2012. № 41. Suppl. 1. P. 5311-5316. DOI: 10.3233/WOR2012-0049-5311.
7. Fertig J., Zeitz G., Blau G. Building Internal Motivation for Worker Competency Certifications: A Critique and Proposal. Human Resource Development Review. 2009. № 8 (2). P. 197-222. DOl: org/10.1177/1534484309333614.

8. Deci E., Ryan R. Intrinsic and extrinsic motivations: classic definitions and new directions. Contemporary Educational Psychology. 2000. № 25. P. 54-67. DOI: 10.1006/ceps.1999.1020.

\section{REFERENCES :}

1. Yemelyanova L. (2017). Stalyj rozvytok agrarnoyi sfery Ukrayiny yak obyekt modelyuvannya [Sustainable development of the agrarian sphere of Ukraine as an object of modeling]. Agrosvit, 10, 30-34.

2. Borodina O. (2017). Imperatyvy komplementarnogo rozvytku v agrarnij sferi [The imperatives of complementary development in the agrarian sphere]. Ekonomika i prognozuvannya, 4, 125-136.

3. Lagodiyenko V., Lagodiyenko N. (2019). Depopulyaciya silskyh terytorij ta motyvaciya najmanyh pracivnykiv u sferi silskogospodarskogo vyrobnycztva Ukrayiny [Depopulation of rural areas and motivation of employees in the agricultural production of Ukraine]. Biznes-navigator, 5-1, 54-61.

4. Erwee Y. (2016). The motivation of farm workers: The case of seven Western Cape fruit farms. Cape Town: Graduate school of Business. Retrieved from: http://gsblibrary.uct.ac.za/researchreports/2016/Erwee. pdf (accessed: 28 September 2019) (in English).

5. Sorauren I. (2000). Non-Monetary Incentives: Do People Work Only for Money? Business Ethics Quarterly, 10 (4), 925-944. DOI: org/10.2307/3857840.

6. Kolstrup C. (2012). What factors attract and motivate dairy farm employees in their daily work? Work, 41 (Suppl. 1), 5311-5316. DOI: 10.3233/WOR2012-0049-5311.

7. Fertig J., Zeitz G., Blau G. (2009). Building Internal Motivation for Worker Competency Certifications: A Critique and Proposal. Human Resource Development Review, 8 (2), 197-222. DOI: org/10.1177/1534484309333614.

8. Deci E., Ryan R. (2000). Intrinsic and extrinsic motivations: classic definitions and new directions. Contemporary Educational Psychology, 25, 54-67. DOI: 10.1006/ceps.1999.1020. 